\title{
A Note on Translation, Transliteration, Names, and Abbreviations
}

ranslations are mine unless otherwise indicated. I have used conventional
spellings for the names of well-known authors but adopted J. Thomas Shaw's System I for transliterating other personal and place names in the text as well as in the discursive parts of the endnotes. For quoting from and citing primary as well as secondary Russian sources, I use Shaw's System II (Library of Congress without diacritics). When quoting from secondary literature in English, I have retained the system used by the author.

The spelling of many Russian personal names has varied from one era (and one text) to the next. I have regularized all names to one standard usage (i.e., "Dmitry" over "Dimitry"). The author of each work I examine made an onomastic choice regarding the man who followed Boris Godunov on the throne. Some referred to him as "False Dmitry," others as "Dmitry the Pretender," still others as "Grishka Otrepev," and yet others as "Dmitry," pure and simple. As a rule, I follow each individual author's usage when discussing that author's text, but in so doing I make no judgments regarding "Dmitry's" "real” identity.

I have used the following abbreviations:

ChOIDR Chteniia $v$ Imperatorskom obshchestve istorii i drevnostei rossiiskikh pri Moskovskom universitete

LOII Trudy Leningradskogo otdeleniia instituta istorii

MERSH Modern Encyclopedia of Russian and Soviet History

RIB Russkaia istoricheskaia biblioteka

SGGD Sobranie gosudarstvennykh gramot $i$ dogovorov khraniashchikhsia $v$ gosudarstvennoi kollegii inostrannykh del

TODRL Trudy otdela drevnerusskoi literatury

ZhMNP Zhurnal Ministerstva narodnogo prosveshcheniia 